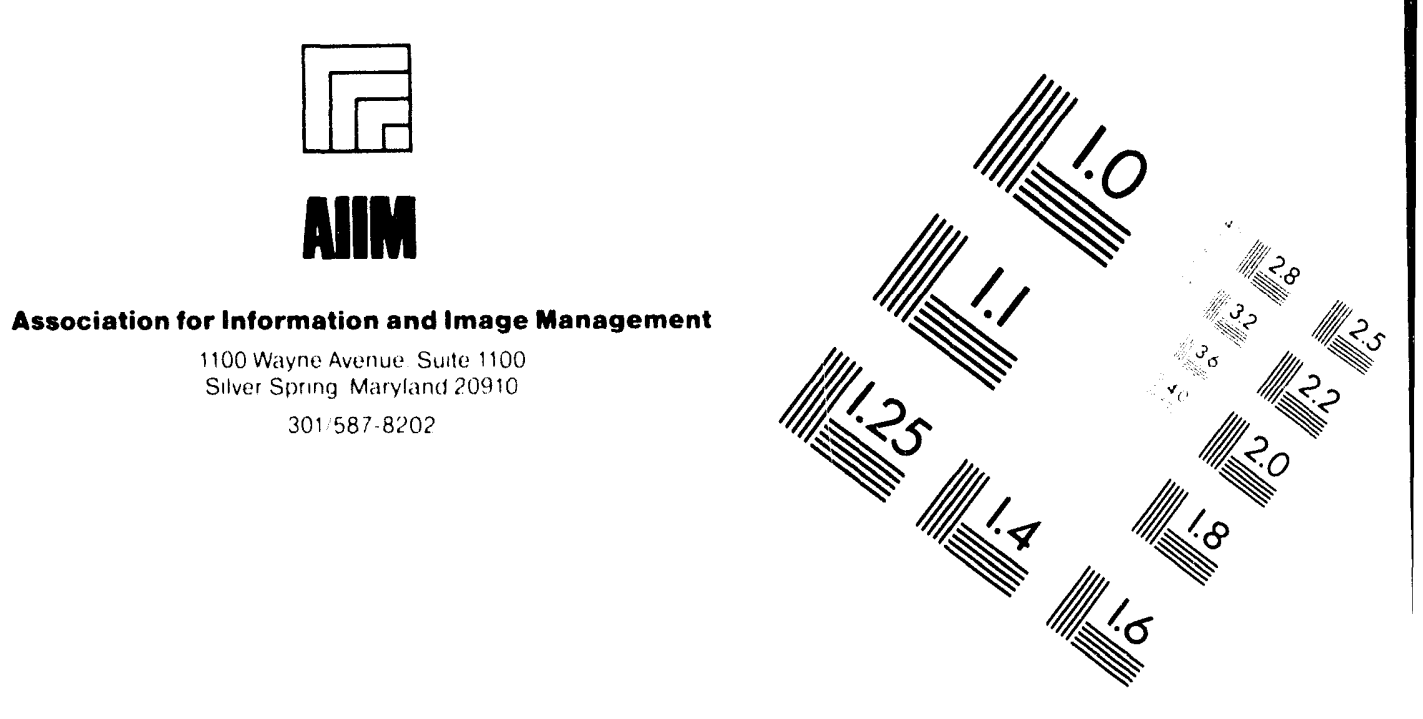

\title{
Centimeter
}

| Inches
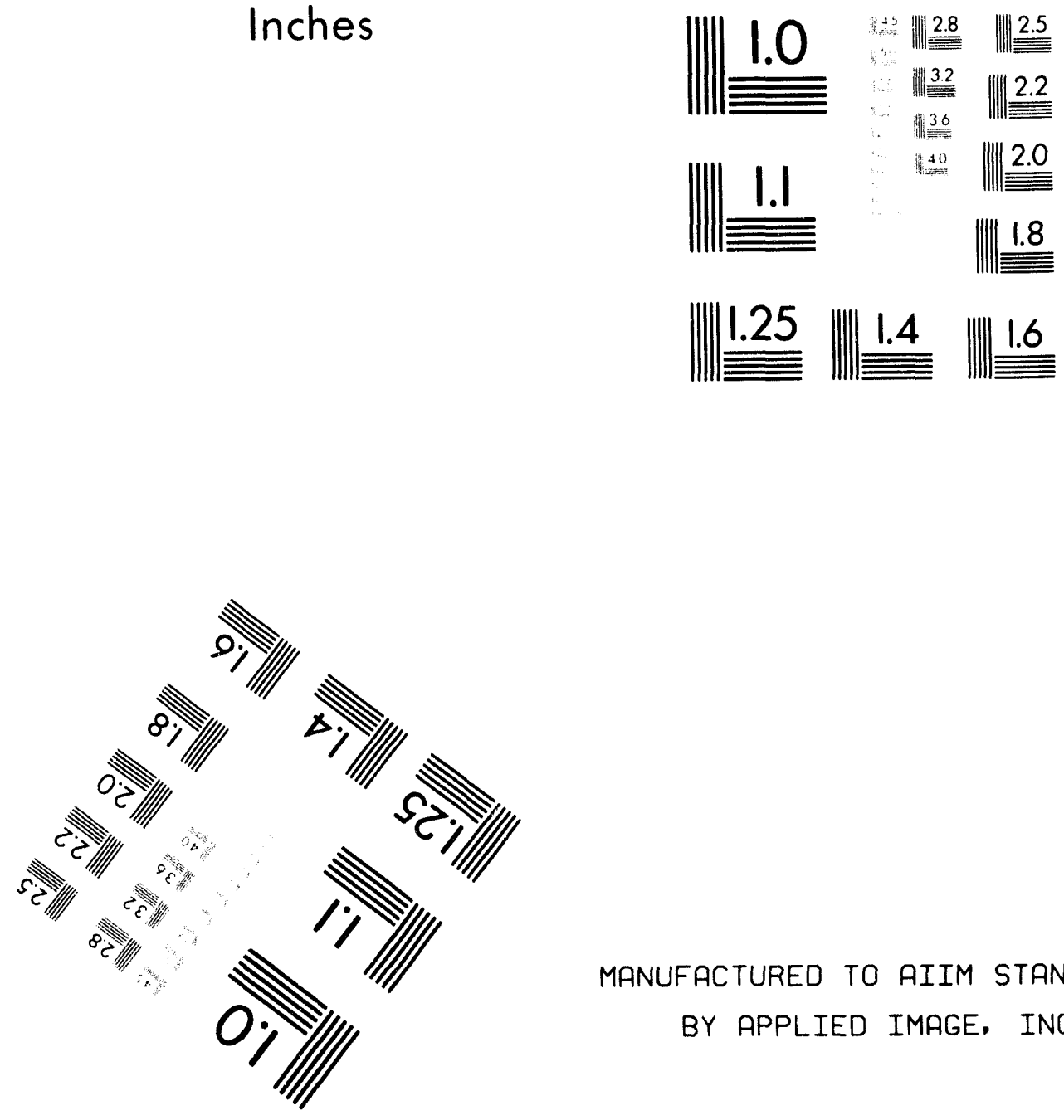

MANUFACTURED TO AIIM STANDARDS

BY APPLIED IMAGE, INC.

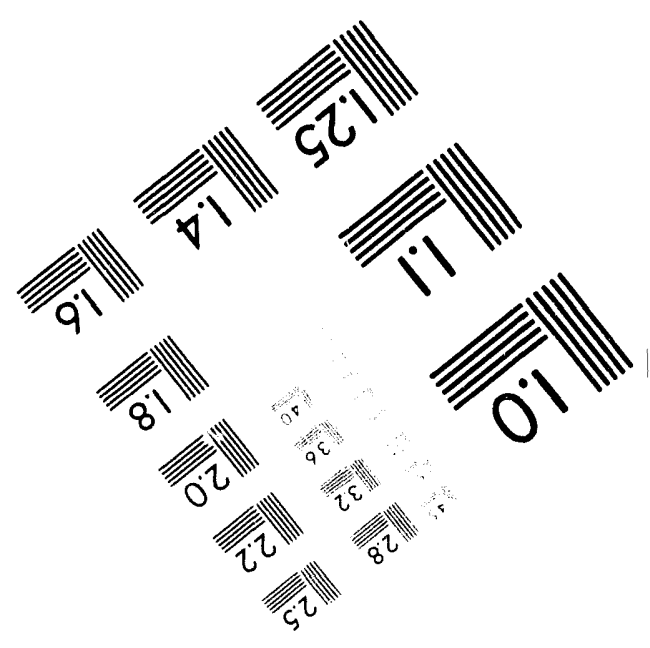



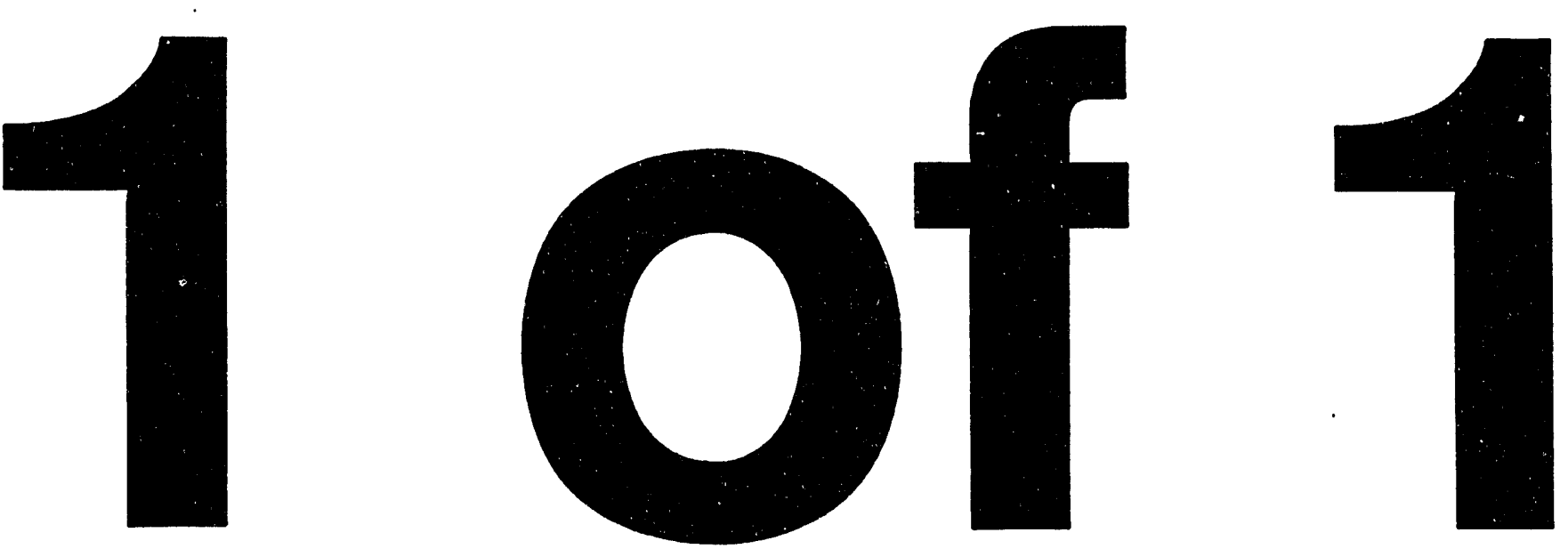


\section{SOLUBILITY OF PLUTONIUM AND WASTE EVAPORATION}

by

D. G. Karraker

Westinghouse Savannah River Company

Savannah River Site

Aiken, South Carolina 29808

This paper was prepared in connection with work done under the above contract number with the U.S.

Department of Energy. By acceptance of this paper, the publishei and/or recipient acknowledges the U. S. Government's right to retain a nonexclusive, royalty-free license in and to any copyright covering this paper, along with the right to reproduce and to authorize others to reproduce all or part of the copyrighted paper.

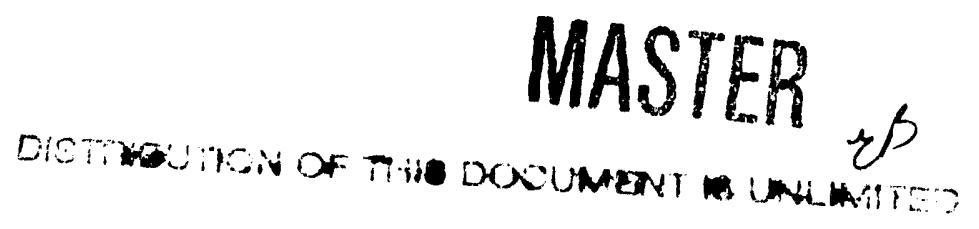




\section{WSRC INTERNAL DISTRIBUTION}

\section{Savannah River Technology Center}

M. J. Barnes, 773-A

F. Beranek, 773-A

N. E. Bibler, 773-A

A. L. Blancett, 773-A

M. R. Buckner, 773-A

W. S. Cavin, 773-A

T. B. Edwards, 773-42A

S. D. Fink, 773-A

S. D. Fleischman, 773-A

F. R. Graham, 773-A

M. S. Hay, 773-A

D. T. Hobbs, 773-A

E. W. Holtzscheiter, 773-A

D. G. Karraker, 773-A

J. R. Knight, 773-A

L. M. Papouchado, 773-A

C. P. Reeve, 773-42A

W. L. Tamosaitis, 773-A

M. C. Thompson, 773-A

R. C. Tuckfield, 773-42A

D. D. Walker, 773-A

E. L. Wilhite, 773-43A

C. R. Wolfe, 773-A

\section{Savannah River Site}

M. C. Chandler, 703-H

J. S. Clemmons, 703-H

P. D. d'Entremont, 703-H

G. K. Georgeton, 703-H

J. E. Marra, 703-H

T. M. Monahon, 703-H

R. A. Scaggs, 703-H 


\section{Keywords: Waste Supernate Pu Solubility in Waste Sludge Washing Pu(IV) Oxidation}

\section{Retention : Permanent}

Classification: U

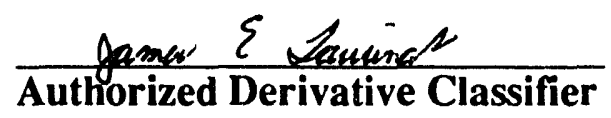

\section{Solubility of Plutonium in Waste Evaporation}

October 22, 1993

\section{Patent Status}

This internal management report is being transmitted without $D O E$ patent clearance, and no further dissemination or publication shall be made of the report without prior approval of the DOE patent counsel. 


\section{DISCLAIMER}

This report was prepared as an account of work sponsored by an agency of the United States Government. Neither the United States Government nor any agency thereof, nor any of their employees, makes any warranty, express or implied, or assumes any legal liability of responsibility for the accuracy, completeness, or usefulness of any information, apparatus, product, or process disclosed, or represents that its use would not infringe privately owned rights. Reference herein to any specific commercial product, process, or service by the trade name, trademark, manufacturer, or otherwise, does not necessarily constitute or imply its endorsement, recommendation, or favoring by the United States Government or any agency thereof. The views and opinions of authors expressed herein do not necessarily state or reflect those of the United States Government or any agency thereof. 
Chemical Process Technology Department

Chemical Technology Section
WSRC-TR-93-578

Revision 0

Solubility of Plutonium in Waste Evaporation

By

D. G. Karraker

Issued: October 18, 1993

Approvals

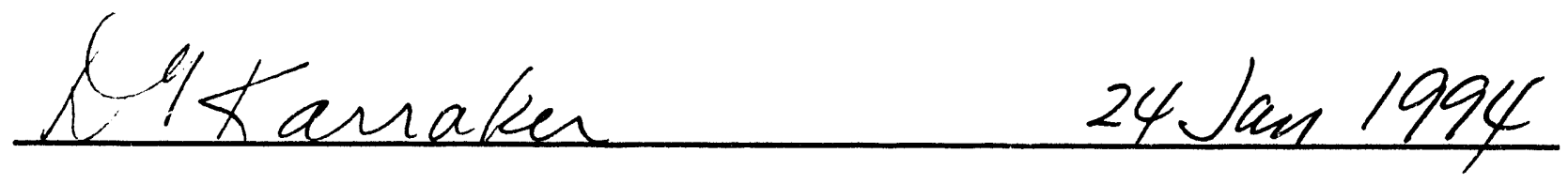

D. G. Karraker, Author, CPT/CTS

Date
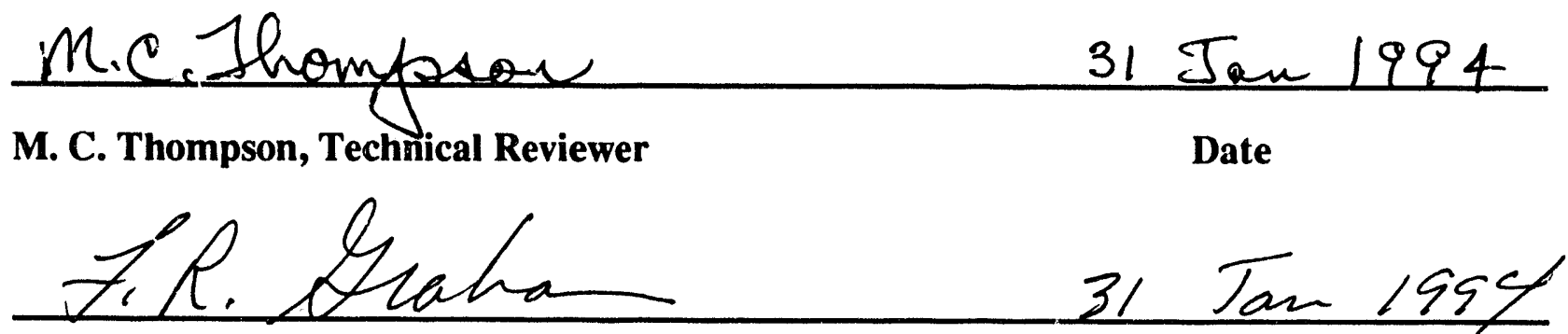

31 Tan 1954

F. R. Graham, Responsible Manager, CPT/CTS

Date

Q. S.9 lan FEB. 4, 1994

J. E. Mara, Customer

Date 


\section{Table of Contents}

Section

1.0 Introduction ...................................................................... 1

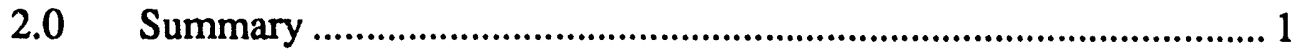

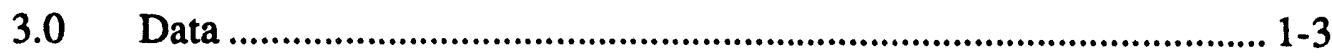

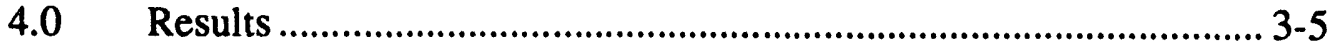

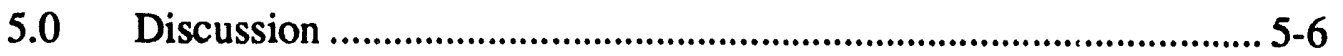

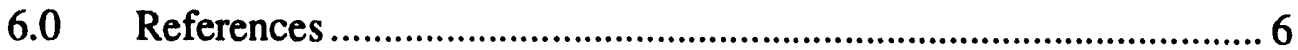

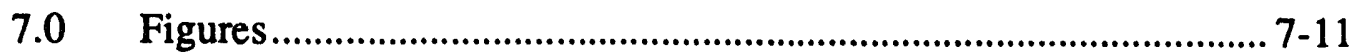


WSRC-TR-93-578

Revision 0

\subsection{Introduction}

Chemical processing of irradiated reactor elements at the Savannah River Site separates uranium, plutonium and fission products; fission products and process-added chemicals are mixed with an excess of $\mathrm{NaOH}$ and discharged as a basic slurry into large underground tanks for temporary storage. The slurry is composed of base-insoluble solids that settle to the bottom of the tank; the liquid supernate contains a mixture of base-soluble chemicals--nitrates, nitrites aluminate, sulfate, etc. To conserve space in the waste tanis, the supernate is concentrated by evaporation. As the evaporation proceeds, the solubilities of some components are exceeded, and these species crystallize from solution. Normally, these components are soluble in the hot solution discharged from the waste tank evaporator and do not crystallize until the solution cools. However, concern was aroused at West Valley over the possibility that plutonium would precipitate and accumulate in the evaporator, conceivably to the point that a nuclear accident was possible. 6 There is also a concern at SRS from evaporation of sludge washes, which arise from washing the base-insoluble solids ("sludge") with ca. $1 \mathrm{M} \mathrm{NaOH}$ to reduce the $\mathrm{Al}$ and $\mathrm{SO}_{4}{ }^{-2}$ content. The sludge washes of necessity extract a low level of $\mathrm{Pu}$ from the sludge and are evaporated to reduce their volume, presenting the possibility of precipitating Pu. Measurements of the solubility of $\mathrm{Pu}$ in synthetic solutions of similar composition to waste supernate and sludge washes are described in this report.

\subsection{Summary}

The solubility of $\mathrm{Pu}$ in synthetic waste supernate decreases from $5 \mathrm{ppm}$ to $1 \mathrm{ppm}$ as the waste is evaporated to ca. $2 \mathrm{M} \mathrm{NaOH}$, then increases to ca. $15 \mathrm{ppm}$ at $5 \mathrm{M} \mathrm{NaOH}$. Synthetic waste supernate diluted $3: 1,10: 1$ and 100:1 with $1 \mathrm{M} \mathrm{NaOH}$ to simulate sludge washes showed increased Pu solubility as the proportion of supernate increased. The Pu solubility was easily reversible. It is proposed that the increase in Pu solubility in high salt- $\mathrm{NaOH}$ solutions is due to partial oxidation of $\mathrm{PuO}_{2} \cdot \mathrm{xH}_{2} \mathrm{O}$ to the more soluble $\mathrm{PuO}_{2}(\mathrm{OH})_{2}$.

\subsection{Data}

\section{Experimental Section}

\section{Synthetic Solutions}

The synthetic waste supernate solutions were prepared from reagent-grade chemicals; the composition $^{1}$ of average waste superate is shown in Table I. Since a clean separation of the waste supernate and the sludge wash solutions is not possible, the sludge wash solutions were considered to be mixtures of the $3 \mathrm{M} \mathrm{NaOH}$ and waste supernate. The mixtures tested were 25,10 and 1 volume $\%$ waste supernate in $1 \mathrm{M} \mathrm{NaOH}$. 
Table I. Average Waste Tank Supernate

Compound

$$
\begin{gathered}
\mathrm{NaOH} \\
\mathrm{NaNO}_{3} \\
\mathrm{NaNO}_{2} \\
\mathrm{NaAlO}_{2}{ }^{*} \\
\mathrm{Na}_{2} \mathrm{CO}_{3} \\
\mathrm{Na}_{2} \mathrm{SO}_{4} \\
\mathrm{NaCl} \\
\mathrm{KF} \\
\mathrm{Na}_{2} \mathrm{C}_{2} \mathrm{O}_{4} \\
\mathrm{Na}_{3} \mathrm{PO}_{4}
\end{gathered}
$$

\section{Concentration, $M$}
1.2
2.4
0.9
0.5
0.2
0.2
0.03
0.02
0.02

* $\mathrm{Al}$ added as $\mathrm{Al}\left(\mathrm{NO}_{3}\right)_{3} \cdot 9 \mathrm{H}_{2} \mathrm{O} ; \mathrm{NaOH}$ and $\mathrm{NaNO}_{3}$ adjusted to compensate.

The solution is prepared in two portions--all chemicals except $\mathrm{Al}\left(\mathrm{NO}_{3}\right)_{3} \cdot 9 \mathrm{H}_{2} \mathrm{O}$ are dissolved in about $3 / 4$ the final volume as one portion. The second portion dissolves $\mathrm{Al}\left(\mathrm{NO}_{3}\right)_{3} \cdot 9 \mathrm{H}_{2} \mathrm{O}$ and the $\mathrm{Pu}(\mathrm{IV})$ nitrate spike in water. The two solutions are mixed by pouring the Al-Pu solution into the basic solution with high agitation. Hydrated $\mathrm{PuO}_{2}$ precipitates from the oversaturated solution after 1-2 hours as a fine green solid.

This oversaturation approach to solubility differs from the undersaturation method used by most investigators $2-5$ which adds the Pu spike as a small volume of concentrated solution. The undersaturation method has the disadvantage that Pu immediately precipitates, and the solution must be stirred and sampled until a steady-state composition is reached. The oversaturation method assures that the initial solution is saturated with $\mathrm{Pu}$ and the $\mathrm{Pu}$ solid phase is a fine material susceptible to re-dissolution. The $\mathrm{Pu}$ precipitate in the waste tanks should be similar to that produced from oversaturation.

To simulate sludge wash solutions, three solutions were mixed: two to make up the spiked synthetic waste supernate and a $\mathrm{NaOH}$ solution to represent the sludge washing solution. As described above, Pu precipitated within a few hours.

\section{Experimental Procedure}

The procedure in all experiments aimed to simulate evaporator operation. The solution was evaporated slowly and sampled at chosen levels of evaporation. Some solutions were diluted and mixed, then re-sampled to determine if the solubility determined during the evaporation could be reproduced for a solution of the same composition. The composition of the waste solutions changed during evaporation as different components crystallized out of the saturated solution. In general, $\mathrm{NaOH}$ and $\mathrm{NaCl}$ concentrations increased, $\mathrm{NaNO}_{3}$ increased, then decreased, $\mathrm{NaNO}_{2}$ and $\mathrm{NaAlO}_{2}$ increased and $\mathrm{Na}_{2} \mathrm{SO}_{4}$, $\mathrm{Na}_{2} \mathrm{CO}_{3}, \mathrm{Na}_{3} \mathrm{PO}_{4}$, and $\mathrm{NaC}_{2} \mathrm{O}_{4}$ crystallized from solution as the evaporation continued. Figures 1 and 2 are graphs of the solution composition as the solution is evaporated 6 . 


\section{Analyses}

Samples were filtered with $0.2 \mu$ pore syringe filter cartridges, and $\mathrm{Pu}$ separated from the filtered solution by anion exchange. The sample was diluted with 4 volumes $9 \mathrm{MHNO}_{3}$, and, after acidifying, treated with $\mathrm{Fe}\left(\mathrm{SO}_{3} \mathrm{NH}_{2}\right)_{2}$ and $\mathrm{NaNO}_{2}$ to assure a $\mathrm{Pu}(\mathrm{IV})$ valence. Column feed, $8 \mathrm{M} \mathrm{HNO}_{3}$ wash and $0.25 \mathrm{M} \mathrm{HNO}_{3}$ elutrient solutions were collected separately, and aliquots counted and pulse analyzed to determine the Pu concentration. Some analyses were repeated two weeks after the original determination with no significant difference in the result.

Speciation experiments with $\mathrm{NaOH}-\mathrm{NaNO}_{3}$ solutions omitted the valence adjustment before anion exchange. Under these conditions, $\mathrm{Pu}$ polymer, $\mathrm{Pu}(\mathrm{V})$ and $\mathrm{Pu}(\mathrm{VI})$ species are not absorbed by the anion column, and were removed in the column washing with $8 \mathrm{M}$ $\mathrm{HNO}_{3}$. $\mathrm{Pu}$ absorbed on the column was eluted with $0.25 \mathrm{M} \mathrm{HNO}$; the ratio of the $\mathrm{Pu}$ found in the column feed and wash effluents to the total Pu was assigned as a measure of oxidized Pu. Attempts to perform similar experiments with the synthetic waste supernate found about $10 \%$ of the $\mathrm{Pu}$ in the combined feed and wash effluents, probably due to $\mathrm{Pu}(\mathrm{IV})$ polymer. The $\mathrm{HNO}_{2}$ formed by acidifying the sample would reduce $\mathrm{Pu}(\mathrm{V})$ and $\mathrm{Pu}(\mathrm{VI})$ to $\mathrm{Pu}(\mathrm{IV})$.

Solutions were titrated for hydroxide, carbonate and aluminate with standard $\mathrm{HCl}$. The procedure involved adding excess $1 \mathrm{M} \mathrm{BaCl}_{2}$ solution to precipitate $\mathrm{BaCO}_{3}$ from one aliquot and titrating to $\mathrm{pH}$ 9.3-10.5 (thymolphthalein indicator) to determine hydroxide, then titrating to $\mathrm{pH}$ 5.2-6.8 (bromcresol purple indicator) to determine aluminate.

Carbonate was estimated by titrating a separate aliquot to $\mathrm{pH}$ 5.5-6.8 and subtracting the titre of the first aliquot. Other species were determined by ion chromatography $\left(\mathrm{NO}_{3}{ }^{-}\right.$, $\mathrm{NO}^{2-}, \mathrm{Cl}^{-}, \mathrm{SO}_{4}{ }^{2-}, \mathrm{C}_{2} \mathrm{O}_{4}{ }^{2-}$, and $\mathrm{PO}_{4}{ }^{3-}$ ) and inductive plasma chromatography $\left(\mathrm{Al}^{3+}\right)$ on identical solutions that contained no plutonium. The composition of solid phases was determined by $x$-ray diffraction.

\subsection{Results}

The solubility of Pu as synthetic waste supernate evaporated is shown in Figure 3, a composite of two separate determinations. The minimum at ca. $2 \mathrm{M} \mathrm{NaOH}$ suggests that there are at least two effects involved in Pu solubility; an attempt to explain this result will be made in this report. The solid phase in these experiments was identified as $\mathrm{PuO}_{2} \cdot \mathrm{xH}_{2} \mathrm{O}$ by $\mathrm{x}$-ray diffraction. The solubilities are in general agreement with those of Delegard ${ }^{3}$ and Hobbs, et al.4,5 on similar solutions. Differences from earlier studies might be expected from the oversaturation approach to solubility and the inclusion of minor components-- $\mathrm{NaCl}, \mathrm{Na}_{2} \mathrm{C}_{2}, \mathrm{O}_{4}, \mathrm{Na}_{3} \mathrm{PO}_{4}, \mathrm{KF}-$ - in these tests but not in those of Delegard or Hobbs, et al. However, these results and those of previous measurements are in reasonable accord.

The results of measurements of the solubility of $\mathrm{Pu}$ as initial mixtures 1,10 and $25 \mathrm{vol} \%$ waste supernate-1M NaOH were evaporated are shown in Figure 4. In general, the $\mathrm{Pu}$ solubility increases as the mixtures are evaporated, and also increases as the proportion of waste supernate increases. The solid phase in these experiments was identified as $\mathrm{PuO}_{2} \times \mathrm{xH}_{2} \mathrm{O}$ by $\mathrm{x}$-ray diffraction. Equilibrium was evidently achieved in these experiments, as the solubilities found when concentrated solutions were diluted agreed with the solubilities found when dilute solutions were concentrated. From these data, both the salt and $\mathrm{NaOH}$ concentrations affect $\mathrm{Pu}$ solubility. 
Two types of experiments attempted to identify a chemical component that was responsible for the increase in Pu solubility as the synthetic waste supernate was evaporated. The first experiment tested the effect of chloride ion on the solubility by evaporating a $1.5 \mathrm{M} \mathrm{NaOH}-0.1 \mathrm{M} \mathrm{NaCl}$ solution, and sampling during boil-down, as before. The results (Figure 5) show a lower solubility than was found for the synthetic waste solution, with about the same dependence on $\mathrm{NaOH}$ concentration that was found in the runs with supernate. This result could be best explained as a valence change of a fraction of the $\mathrm{Pu}$ as the solution became more concentrated. An increased solubility due to the increase in chloride ion would not show the minimum found at $3 \mathrm{M} \mathrm{NaOH}$.

A second series of experiments aimed at identifying the chemical component involved evaporating a $\mathrm{NaOH}$ solution $50 \%$, measuring the solubility, then diluting back to the original volume, adding a component, evaporating this solution $50 \%$, an i repeating this procedure for the major components. The results of these experiments (Table II) actually showed no effect for any of the components tested.

Table II

Effect on Solution Components on Pu Solubility

Component

$2 \mathrm{M} \mathrm{NaOH}$

$2 \mathrm{M} \mathrm{NaOH}-4.8 \mathrm{M} \mathrm{NaNO}_{3}$

$2 \mathrm{M} \mathrm{NaOH}-4.8 \mathrm{NaNO}_{3}-1.8 \mathrm{M} \mathrm{NaNO} 2$

$2 \mathrm{M} \mathrm{NaOH}-4.8 \mathrm{M} \mathrm{NaNO}-1.8 \mathrm{M} \mathrm{NaNO}_{2}-1 \mathrm{M} \mathrm{NaAlO}_{2}$

plus $0.04 \mathrm{M} \mathrm{KF}$
Pu, mg/L

0.34

0.46

0.40

The inference that $\mathrm{Pu}$ was oxidized by $\mathrm{O}_{2}$ (air) in high salt- $\mathrm{NaOH}$ solutions was also investigated by speciation experiments on $\mathrm{NaOH}-\mathrm{NaNO}_{3}$ solutions. $\mathrm{Pu}(\mathrm{IV})$ might be oxidized to $\mathrm{Pu}(\mathrm{V})$ by

$4 \mathrm{PuO}_{2} \bullet \mathrm{H}_{2} \mathrm{O}+\mathrm{O}_{2} \cdots 4 \mathrm{PuO}_{2}(\mathrm{OH})$

followed by the disproportionation

$2 \mathrm{PuO}_{2}(\mathrm{OH})-\cdots>\mathrm{PuO}_{2}+\mathrm{PuO}_{2}(\mathrm{OH})_{2}$

or directly, as

$2 \mathrm{PuO}_{2} \bullet \mathrm{H}_{2} \mathrm{O}+\mathrm{O}_{2}+2 \mathrm{H}_{2} \mathrm{O} \cdots 2 \mathrm{PuO}_{2}(\mathrm{OH})_{2}$

Anion exchange will absorb $\mathrm{Pu}^{+4}$ as the hexanitrato complex, but will not absorb $\mathrm{Pu}(\mathrm{IV})$ polymer, $\mathrm{Pu}(\mathrm{V})$ or $\mathrm{Pu}(\mathrm{VI})$. The column feed and wash effluents were assumed to be a mixture of $\mathrm{Pu}$ polymer, $\mathrm{Pu}(\mathrm{V})$ and $\mathrm{Pu}(\mathrm{VI})$; the ratio of non-absorbed $\mathrm{Pu}$ to total $\mathrm{Pu}$ during evaporation of a $0.35 \mathrm{M} \mathrm{NaOH}-2 \mathrm{M} \mathrm{NaNO}_{3}$ is shown in Table 'II. 
Table III

\section{Non-Absorbing Pu to Absorbing Pu Ratio}

NaOH, M

0.35

0.64
Pu, mg/L

0.71

1.1

1.4

$$
[(\mathbf{P u}(\mathbf{V})+\mathbf{P u}(\mathbf{V I})] / \mathbf{P u} \text { Total }
$$

0.18

0.38

0.42

Solution diluted to original volume with $1 \mathrm{M} \mathrm{NaOH}$ added
1.5
0.28
0.34
1.98
0.49
0.30
3.69
2.82
0.46
4.76
10.8
0.41

The correlation is rather imperfect, but the measurements that show higher solubilities also show a higher ratio of $[\mathrm{Pu}(\mathrm{V})+\mathrm{Pu}(\mathrm{VI})] /$ total $\mathrm{Pu}$.

The Pu solubility was also measured in $20 \mathrm{M} \mathrm{NaOH}$, performed in a capped vial to prevent $\mathrm{O}_{2}$ and $\mathrm{CO}_{2}$ access to the solution. The $\mathrm{Pu}$ solubility found was $34 \mathrm{mg} / \mathrm{L}$ with a ratio of 0.6 . The solution was then adjusted to $0.01 \mathrm{M} \mathrm{H}_{2} \mathrm{O}_{2}$, stirred overnight, and then re-measured as $334 \mathrm{mg} / \mathrm{L}$; ratio 0.4 . A second $0.01 \mathrm{M}$ addition of $\mathrm{H}_{2} \mathrm{O}_{2}$ reduced the solubility to $98 \mathrm{mg} / \mathrm{L}$ after one week. An attempt to reduce the solution with $\mathrm{Fe}_{3} \mathrm{O}_{4}$ lowered the solubility to $66 \mathrm{mg} / \mathrm{L}$, with a $[\mathrm{Pu}(\mathrm{V})+\mathrm{Pu}(\mathrm{VI})] / \mathrm{Pu}$ total ratio of 0.9 . The effect of the $\mathrm{Fe}_{3} \mathrm{O}_{4}$ treatment is presumed to stabilize $\mathrm{Pu}(\mathrm{V})$; other solubilities are presumed to be $\mathrm{Pu}(\mathrm{IV})-\mathrm{Pu}(\mathrm{VI})$ mixtures. These solutions are concentrated enough to show some color; sophisticated spectral measurements might positively identify the valence state of the $\mathrm{Pu}$ in solution.

\subsection{DISCUSSION}

The increase in Pu solubility with evaporation of the waste supernate indicates that Pubearing solids will not accumulate in the waste evaporator as long as the evaporation ratio is greater than 3 to 1 . The Pu solubility was found to be reversible in these solutions, so should $\mathrm{Pu}$ be crystallized out of solution, a further evaporation of the solution would redissolve the precipitate. This agrees with experience at West Valley, where an evaporator clean-out found substantial uranium accumulation but no unusual $\mathrm{Pu}$ accumulation in the evaporator. 6

The minimum in Pu solubility at ca. $2 \mathrm{M} \mathrm{NaOH}$ indicates that two (or more) effects are involved in determining Pu solubility in strong base-high salt solutions. Air oxidation of some of the $\mathrm{Pu}(\mathrm{VI})$ to the more soluble $\mathrm{Pu}(\mathrm{V})$ or $\mathrm{Pu}(\mathrm{VI})$ is considered the most likely explanation. The high salt- $\mathrm{NaOH}$ solutions could affect the oxidation potentials 
sufficiently to allow some oxidation to occur, with an accompanying increase in $\mathrm{Pu}$ solubility.

Although $\mathrm{Pu}(\mathrm{V})$ is a possible valence, the experiments with $\mathrm{H}_{2} \mathrm{O}_{2}$ and $\mathrm{Fe}_{3} \mathrm{O}_{4}$ suggest that $\mathrm{Pu}(\mathrm{VI})$ is the probable valence of the oxidized species. $\mathrm{Pu}(\mathrm{V})$ has been found as the predominate valence in $5 \mathrm{M} \mathrm{NaCl}$ in neutral $\mathrm{pH}$ solution 7 and carbonate ground waters 8 , but would be expected to disproportionate in strong base 9 .

The results reported here could be modified by the effects of oxidizing or reducing species produced by the radiation field in the SRS waste tanks. Previous studies ${ }^{7}$ have found that radiation produces $\mathrm{ClO}^{-}$in chloride solutions, which then oxidizes $\mathrm{Pu}(\mathrm{IV})$ to $\mathrm{Pu}(\mathrm{V})$. The variety of components in SRS waste supernate raises the possibility that either oxidizing or reducing agents, or both, might be formed in the intense radiation field of the waste tanks.

Acknowledgements

The author is indebted to D. Walker and C. Parkman (Analytical Development Section) for experimental assistance.

\subsection{REFERENCES}

1. D. D. Walker and B. A. Hamm, WSRC-RP-89-1303, "Material Balance and Planned Operating Schedule for the In-Tank Process" December 27, 1989.

2. C. H. Delegard and S. A. Gallegher, RHO-RE-ST3 P, "Effects of Hanford High Level Waste Components on the Solubility of Cobalt, Strontium, Neptunium, Plutonium, and Americium" October 1983.

3. C. H. Delegard, RHO-RE-SA-75 P, "Solubility of $\mathrm{PuO}_{2} \bullet \mathrm{xH}_{2} \mathrm{O}$ in Alkaline Hanford High-Level Waste Solution" May 2, 1985.

4. D. T. Hobbs, T. B. Edwards and S. D. Fleischman, WSRC-TR-93-056, "Solubility of Plutonium and Uranium in Alkaline Salt Solutions", February 12, 1993.

5. D. T. Hobbs and T. B. Edwards, "Solubility of Plutonium in Alkaline Salt Solutions" WSRC-TR-93-131, February 26, 1993.

6. D. G. Karraker, "Solubility of Uranium in Synthetic Waste Supernate", WSRC-TR93-433, August 1993.

7. K. Büpplemann and J. I. Kim, "Chemisches Verhalten von Plutonium in chloridhalten wässrigen Losungen", RCM-01088, Institut für Radiochemie, der Technischen Universität München, Juni 1988.

8. H. Nitsche, A. Müller, E. M. Standifer, R. S. Deinhammer, K. Becraft, T. Prussin and R. C. Gatti, "Dependence of Actinide Solubility and Speciation on Carbonate Concentration and Ionic Strength in Groundwater", Radiochim. Acta, 58, 27, (1992).

9. H. Capdevila, P. Vitorge and E. Giffaur, "Stability of Pentavalent Plutonium", Radiochem. Acta, 58, 45, (1992). 
Figure 1.

Major Salt Concentrations in Evaporated Synthetic Waste Supernate

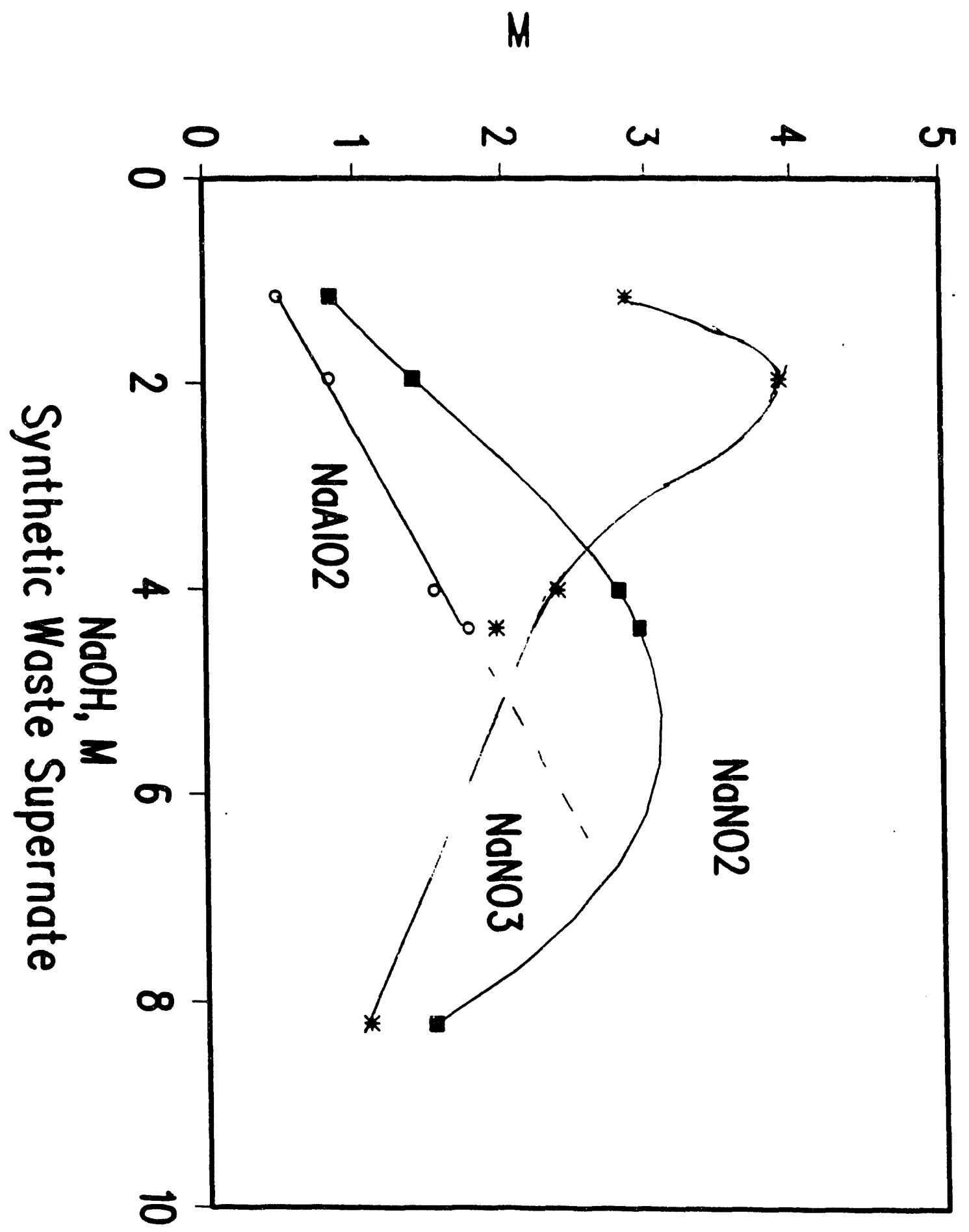


Chemical Process Technology Department

Chemical Technology Section

Figure 2.

Minor Salt Concentrations

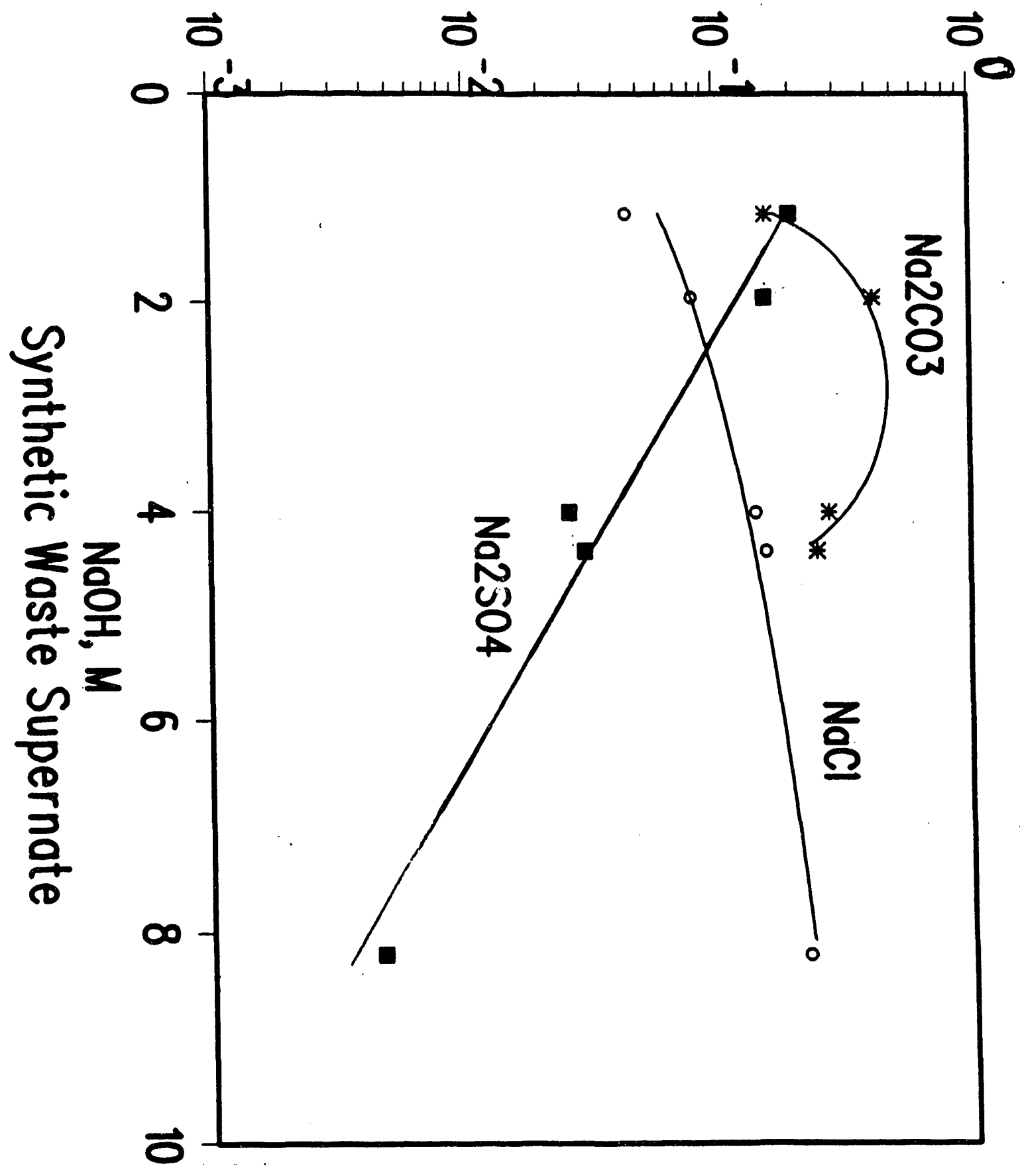


Figure3.

Plutonium Solubility in Evaporated Waste Supernate

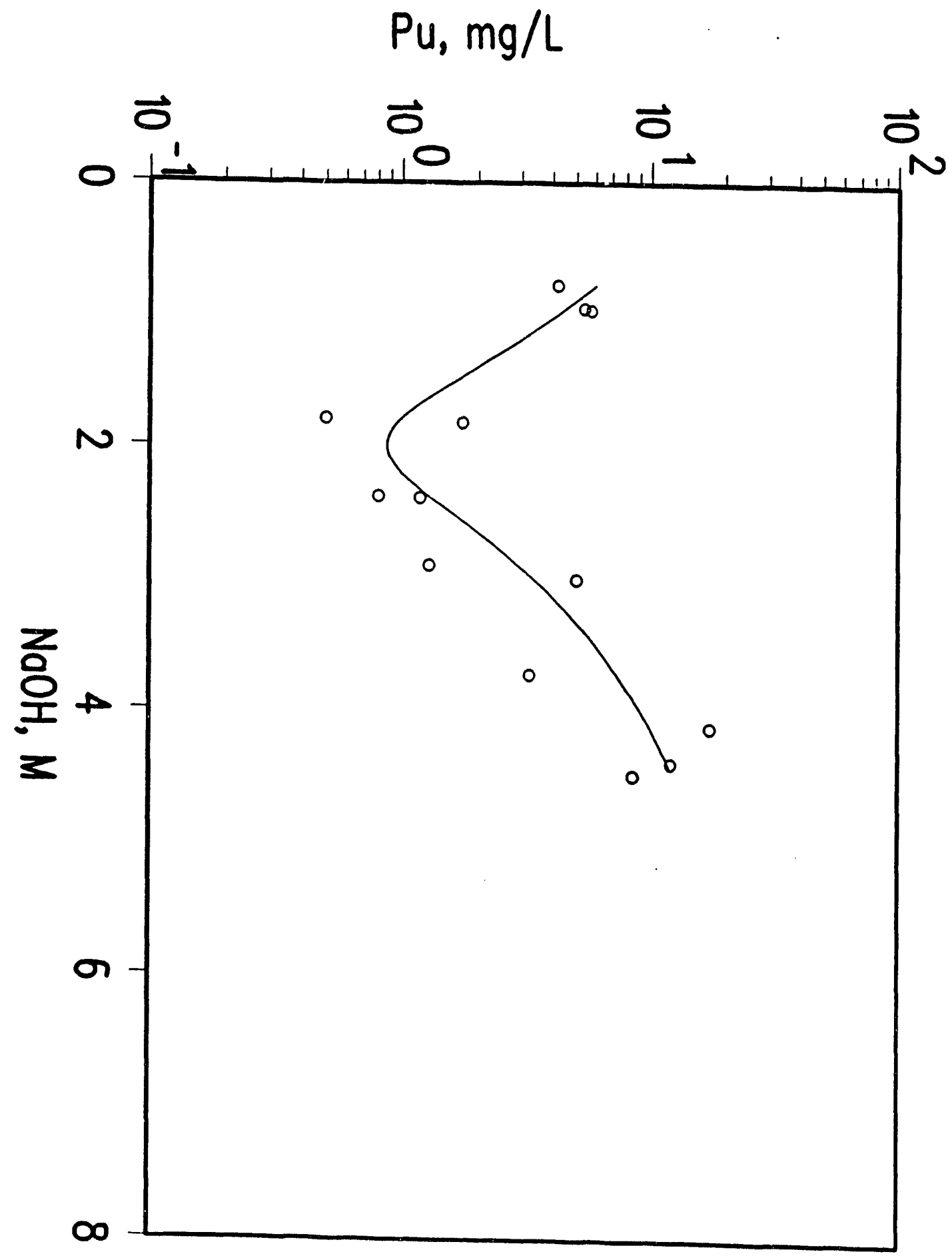


Figure 4.

Plutonium Solubility in Simulated Sludge Wash Solutions

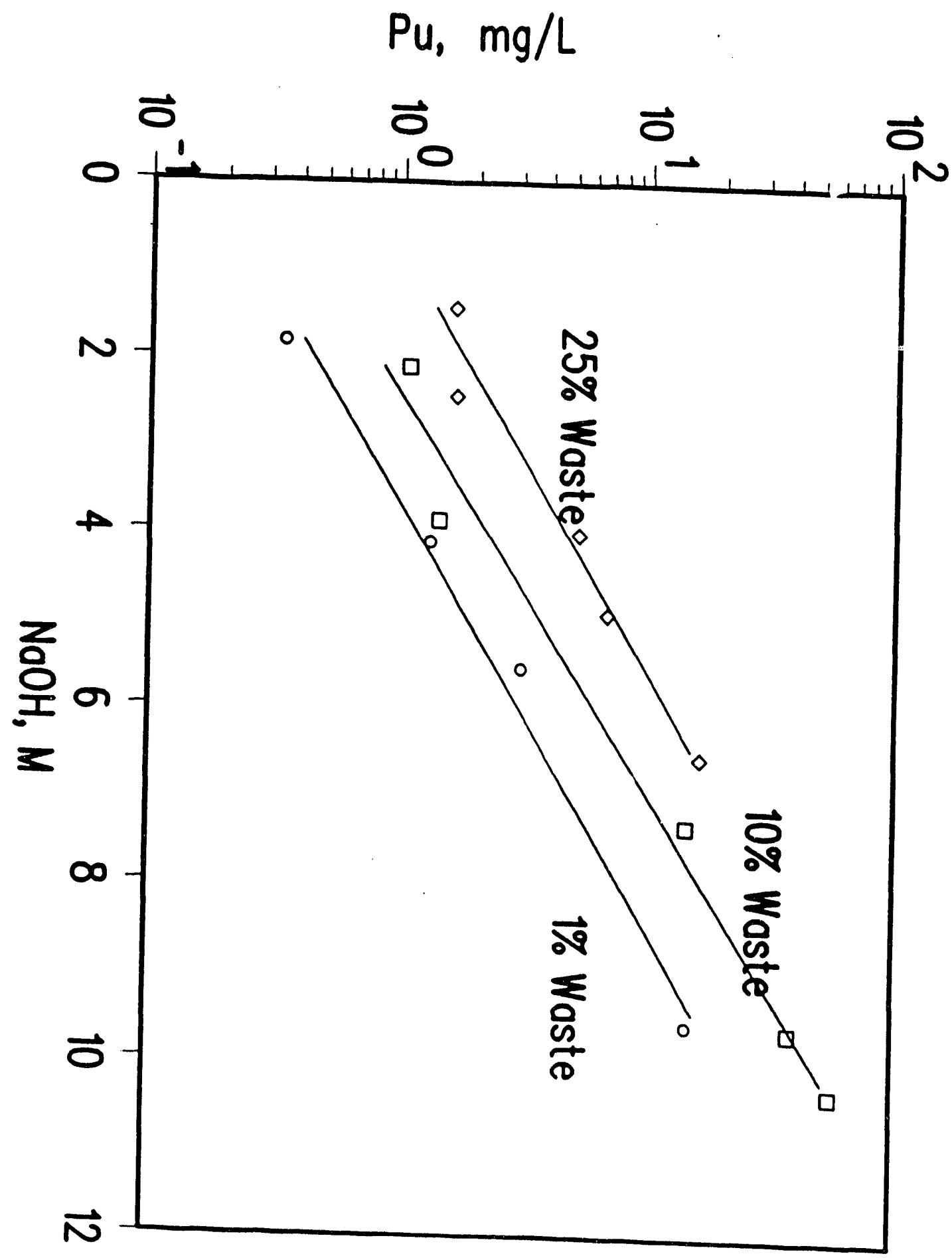


Figure 5.

Plutonium Solubility in $\mathrm{NaOH}-\mathrm{NaCl}$ Solutions. Initial Concentrations, $1.5 \mathrm{M}$ $\mathrm{NaOH}, 0.1 \mathrm{M} \mathrm{NaCl}$

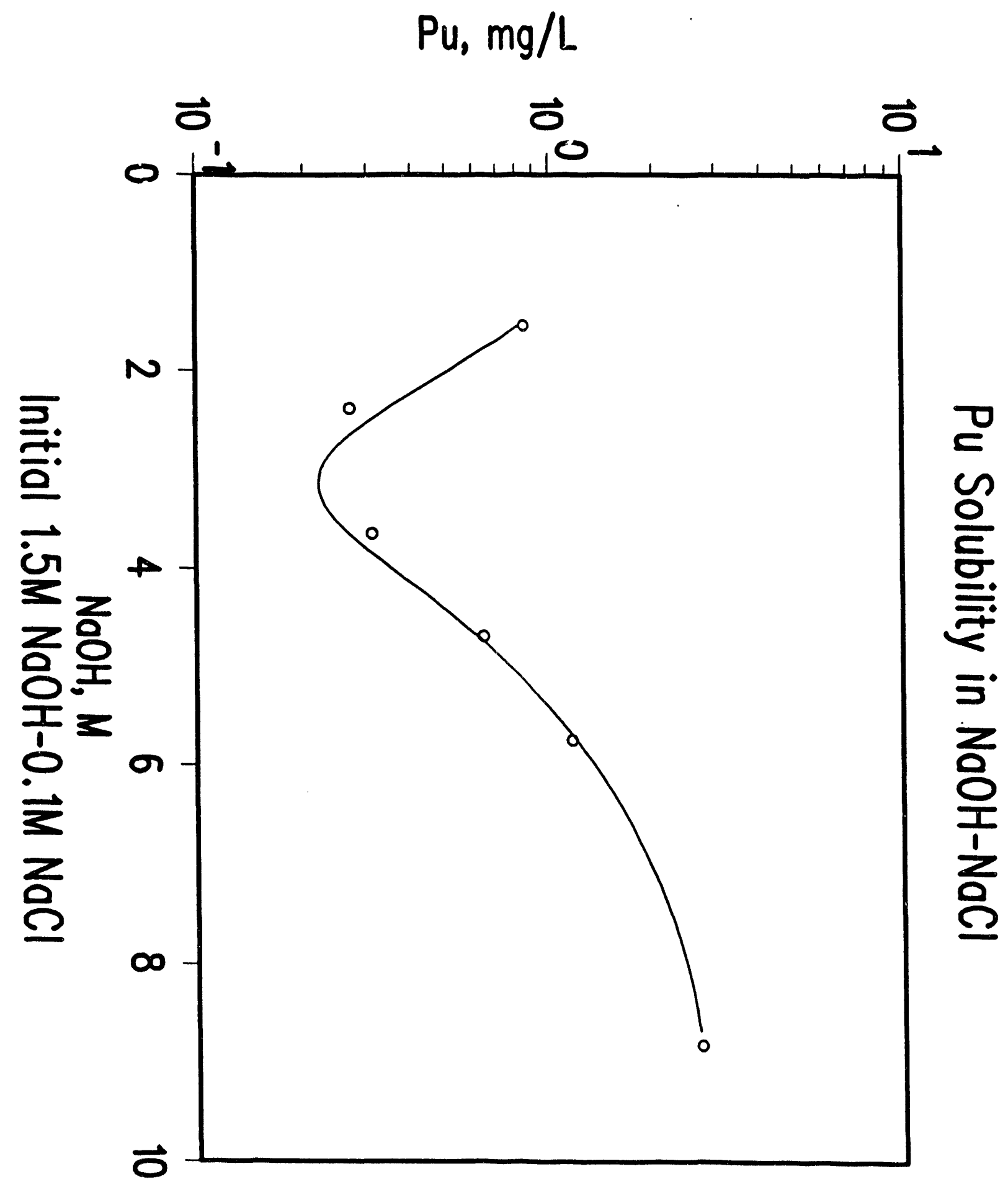



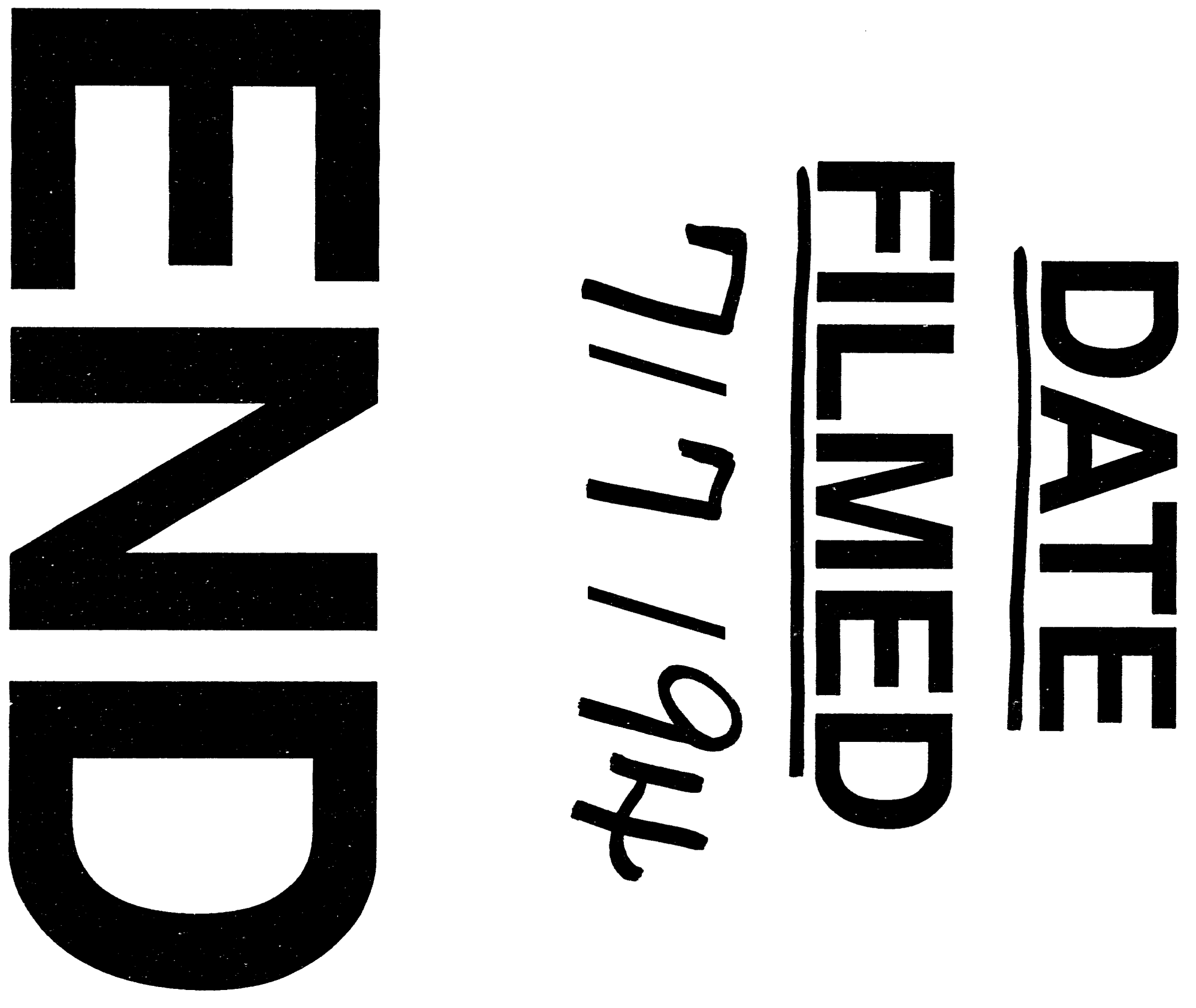
